\title{
MARXIST EDUCATION AND TEACHER EDUCATION AGAINST CAPITALISM IN NEOLIBERAL/ NEOCONSERVATIVE/ NEOFASCIST/ TIMES
}

\author{
Dave Hill ${ }^{1}$ \\ Middlesex University, London, UK
}

\section{Abstract}

In this article I analyse global and national neoliberalisms- economic and social class war from above- neoconservatisms which are leading to and connected with NeoFascisms- with their scapegoating, racism, xenophobia, misogyny, heterophobia, militarism and the attacks on dissent- whether electoral, media, or from academics/ universities and workers' organisations and actions. Six prime examples are Erdogan in Turkey, Bolsonaro in Brazil, Trump in the USA, Orban in Hungary, the Law and Justice government in Poland, and the racist government in Italy, in effect led by Salvini. Across Europe Far-right anti-immigrant, xenophobic and ultra nationalist authoritarian parties are recruiting and becoming electorally significant- and, in some cases, significant on the streets. Critique social democratic reformist parties and governments for adopting neoliberal austerity policies and thereby becoming delegitimised, together with the too-often 'accomodationist' trade union and party leaderships. and critically examine prospects for left social democracy as represented, for example, by the Jeremy Corbyn led Labour Party in the UK. Much of the article is devoted to the resistant and the revolutionary role of teachers, academics and education/ cultural workers in different arenas, from national and local electoral and direct action politics/ Focusing on Critical Education, Critical Educators, Marxist Education, Marxist Educators, I seek to address four aspects of education: pedagogy, the curriculum, resistance in the classroom and the hidden curriculum, and the structure of schooling nationally and locally (within-school). I conclude by setting out what is specifically Marxist about the proposals set out. These are: (1) Class Analysis: the Capital-Labour Relation; (2) Capitalism must be replaced by Socialism and that change is Revolutionary; and (3) Revolutionary Transformation of Economy and Society needs to be preceded by and accompanied by a Class Programme, Organisation, and Activism. Regarding capitalism, our task is to replace it with democratic Marxism, to lead, firstly, into socialism, and ultimately, into communism. As teachers, as educators, as cultural workers, as educational, union and party activists, as intellectuals, we have a role to play.

Keywords: Marxist education. Neoliberalism. Neoconservatisms. Neofascisms.

\footnotetext{
${ }^{1}$ Marxist trade union and political activist, Editor of The Journal for Critical Education Policy Studies, Emeritus / Visiting Professor at Anglia Ruskin University, Cambridge and Chelmsford, UK, Middlesex University, London, UK, and the National and Kapodistrian University of Athens, Greece
} 


\section{Introduction}

$\mathrm{n}$ this article I analyse global and national NeoLiberalisms- economic and social class war from above- NeoConservatisms, and their connection with NeoFascisms- with their scapegoating, racism, xenophobia, misogyny, homophobia, militarism and the attacks on dissent- whether electoral, media, or from academics/ universities and workers' organisations and actions.

Six prime examples (there are others) are Erdogan in Turkey, Bolsonaro in Brazil, Trump in the USA, Orban in Hungary, the Law and Justice (PiS) government in Poland, and the racist government in Italy, in effect led by Salvini. Across Europe Far-right antiimmigrant, xenophobic and ultra nationalist authoritarian parties are recruiting and becoming electorally significant- in France, Finland, Sweden, UK, Austria, Germany, and, in some cases, significant on the streets.

Social democratic reformist parties and governments should be critiqued for adopting neoliberal austerity policies and thereby becoming delegitimised, for abandoning the material interests of he working class. So, too, should the too-often 'accomodationist' or 'incorporated' trade union and party leaderships. This must lead to a critical examination of prospects for left social democracy as represented, for example, by the Jeremy Corbyn led Labour Party in the UK.

I then proceed to highlight, and call for, the resistant (resisting neoliberalism, neoconservatism and neofascism) and the revolutionary role of teachers, academics and education/ cultural workers in different arenas, from international, to national, to local electoral - and direct action- politics. Focusing on Critical Education, Critical Educators, Marxist Education, Marxist Educators, I seek to address four aspects of education: pedagogy, the curriculum, resistance in the classroom and the hidden curriculum, and the structure of schooling nationally and locally (within-school).

I conclude by setting out what is specifically Marxist about the proposals set out. These are: (1) Class Analysis: the Capital-Labour Relation; (2) Capitalism must be replaced by Socialism and that change is Revolutionary; and (3) Revolutionary Transformation of Economy and Society needs to be preceded by and accompanied by a Class Programme, Organisation, and Activism.

Regarding capitalism, our task is to replace it with democratic Marxism, to lead, firstly, into socialism, and ultimately, into communism. As teachers, as educators, as cultural workers, as educational, union and party activists, as intellectuals, we have a role to play. 


\section{Capitalism and the class war from above: neoliberalism, neoconsevatism, neo- fascism}

Neoliberal and neoconservative policy differs in different national and historical contexts. But its aims- at maximising and aggrandising private capitalist profit- do not vary. These aims are fundamental to capitalism. This maximisation of profit is at the expense of both the social wage (welfare benefits/ public services) and the individual wage and working conditions and rights of workers, such as education workers. This intensification of the extraction of surplus value from the labour power of workers, including education workers, has many terms, such as 'Kleptocratic Capitalism', 'Turbo-Capitalism' and 'Class War from Above' (Giroux, 2004, Harvey 2005, Hill, 2012, 2013), or 'Immiseration Capitalism' (Hill 2012, 2013, 2017a).

Commentators from across the political spectrum are in general agreement that in a vigorous 'class war from above' (since the economic crisis of the mid-1970s, (the oil crisis') the capitalist class has been incredibly and exponentially in wresting back from the working class a greater and greater share of public wealth, of the share of national income and wealth, across much of the capitalist world (Picketty, 2014, Oxfam, 2018). As El-Gingihy (2018) points out, the 'wealthiest eight billionaires ... have as much wealth as the bottom half of the global population, ... 3.5 billion people. the equivalent figure was ... 62 wealthiest billionaires in $2016 \ldots$ in 2010 it was more than 300'. And as billionaire Warren Buffet has put it, 'There's class warfare, all right, but it's my class, the rich class, that's making war, and we're winning.'

As part of the international and national divisions of labour, capitalist profitability reigns supreme, whether neoliberal - neoconservative capitalism in the Anglo-Saxon world, or in post-Soviet capitalism in Russia, or in Modi's neoliberal-neoconservative Hindu supremacist India, an example of post-colonial capitalism. All are oligarchic, plutocratic and kleptocratic. The victims are the environment, workers' and their rights and conditions and social rights- and regions- and their populations- deemed unprofitable for profit. So, in the interests of capital accumulation, of the maximisation of private oligarchic profit, whole regions are devastated, impoverished, written off. This is as true of Detroit, or the South Wales valleys and northern ex-coal minefields on England, of impoverished regions in Russia, Bihar and Uttar Pradesh in India, and whole countries such as Bulgaria- in the postSoviet capitalist economies. We are witnessing the global, internal and external migrations from poverty and the crippling of the social state, and the impoverishment, pauperisation, 
absolute immiseration of internal and external migrant labour- people, humans, familieswho live, love, and labour, their sinews aching with the intensification of the extraction of surplus value from their labour power. The rich grow fatter and richer and ever more gluttonous. The poor, the migrants, the working classes, die early and sick. Written off $s$ useless to capitalism. Worse than that, as a 'drain', a drag on capitalism. No life if retirement dignity for billions.

Some conservatives argue that inequality is not only 'natural' but that it is also 'desirable', since it fuels envy, aspiration, competition, hard work. Such arguments are global, made, for example, by the Conservatives and Liberal Democrats in the UK, the AKP in Turkey, the BJP in India, right-wing and centre-right governments everywhere.

For Marxists, capitalism is not just immoral and a case of 'oppression'. It is that capitalism is exploitative. It is based on economic exploitation. However, most Marxists and socialists (the terms are slightly different and used differently in different historical and geographical situations) point to the need for 'agency' for action, for the need for Marxist militants and activists to work to develop class consciousness, to use Marx and Engels' phrase (Marx and Engels, 1848) the development of the working class as a (conscious) 'class for itself', instead of a 'class in itself' with economically similar positions in relationship to the ownership of the means of production and similar social relations of production, but with no sense of class unity or class struggle (Marx, 1847). Freire used the term, 'conscientization' (Freire, 1972). Marxists believe in 'agentist' activism, in the need to develop strong political organizations to fight for major social and economic, revolutionary, change. For Marxists today, socialism and Marxism are not 'inevitable', they have to be fought for. Marxists believe that the point is not simply to describe the world but to change it. In Marx's words, 'The philosophers have only interpreted the world, in various ways; the point is to change it' (Marx, 1845).

Capitalism is undoubtedly, for Marxists, immoral. Workers die, and get sick and disabled, far earlier than bankers and Chief Executive Officers (CEOs) and 'royal' families. Workers, especially the unskilled and semi-skilled manual strata of the working class, have unhealthier lives, inferior education and health and retirement services than 'the rich' (Hill, 2018). 
Classes are internally stratified, each class has different layers, and within those layers, the patterns and extents of oppression/ discrimination and economic exploitation/ super -exploitation is gendered and 'raced'. Thus, within the working class, professional and managerial strata lead longer and healthier lives in general, than the poorer and the manual strata. And this differentiation is deliberately encouraged by Capital and its media. Capitalist politicians and media 'divide and rule'- whipping up hatred and division between black and white, men and women, LGBT and straight, immigrant and non-immigrant, public sector employees and private sector employees, employed and unemployed, 'deserving poor' and 'undeserving poor', 'roughs' and 'respectables', low paid workers and so-called 'middle class' (professional, supervisory) sections of the working class).

Indeed, Marxists see Fascism and Nazism in 1920s, 1930s and 1940s Europe, and some examples of contemporary extreme nationalism and xenophobia since then (as with the Nazi 'Golden Dawn party being elected to the Greek parliament in 2012 and to the European Parliament in 2014 and the increased strength of he xenophobic nationalist right in the European elections of 2019) as a throw of the dice by capitalists desperate to 'stop the red menace', to stop communism- or even to stop the fairly moderate left social democracy of Jeremy Corbyn in the UK. Capitalist classes and media give substantial support to nationalist, anti-immigration, right-wing parties such as UKIP, the United Kingdom Independence Party, which topped the poll in the UK the 2014 European Parliament elections in the UK) and the Brexit Party, which topped the poll in the 2019 European Parliament elections in the UK.

But, to repeat, where Marxist analysis of economic, social, human rights policy, and education policy, differs from other critique- even the vibrant left democrats (who are not socialist) like Henry Giroux- is that Marxists, firstly, prioritise class analysis, secondly, go beyond critique, go beyond deconstruction, into reconstruction- into proposals for a fundamental change in society and economy, a socialist economy. And, thirdly, Marxists go beyond proposal/ programme into activism.

PRE-/ PROTO-/ QUASI-/ NEO-FASCIST TIMES (see Bellamy Foster, 2017, O'Toole, 2019, Rosen, 2019, Thomas, 2019).

We Marxists analyse and accuse. Salvini is on trial here. So is Bolsonaro. So is Erdogan, So is Orban. So is Trump, So is the PiS government in Poland. If it looks like a 
rotten stinking fish, if it smells like a rotten stinking fish, if it acts like a rotten stinking fish, if it stinks like a rotten fish. Then it is a rotten stinking fish.

If it looks like a fascist, if it smells like a fascist, if it acts like a fascist, then it is a fascist. Even if the label on the box says democratic and it dresses in a pin-striped suit.

Salvini, Erdogan, Bolsonaro, Orban, Trump, the Law and Justice Party in Poland, all say they are democrats. They stir hatred. They sir violence. They stir suppression of critical thought. They stir suppression of critical thought in the universities. They intimidate those of us who protest. They threaten. They enact. They destroy civility. They peddle fear, and hatred. As Fintan O'Toole (2019) puts it, they (he calls them 'pre-Fascists') ' You have to undermine moral boundaries, inure people to the acceptance of acts of extreme cruelty'. He continues, 'this allows the members of that (out)group to be dehumanised. Once that has been achieved, you can gradually up the ante, working through the stages from breaking windows to extermination'.

And violence results. Roma and immigrant camps torn down in Italy, LGBT beaten in the streets and on public transport, in Brazil and the UK and Russia. Babies crying, torn from their mothers in Trump's detention camp cages in the USA, boatloads of African immigrants turned away from Italy's ports, Brazil's murderous military dictatorship of the 1960s-1980s lauded by Bolsonaro.

These lions of the capitalist media, Salvini, Bolsonaro, Erdogan, Orban, the PiS in Poland, Trump- all in governmental power, all elected, these 'democratic' and democratically elected far- rightists open the way to the next stage, beyond their quasifascism, their pre-fascism, call it what you will, their proto-fascism, their neo-fascism.

The muscles that the propaganda machines need for defending the indefensible are being toned up. Millions and millions of Europeans and Americans are learning to think the unthinkable. So what if those black people drown in the sea? So what if those brown toddlers are scarred for life? They have already, in their minds, crossed the boundaries of morality. [...] But the tests will be refined, the results analysed, the methods perfected, the messages sharpened. And then the deeds can follow. (O'Toole, 2019).

And the deeds do follow. These elected quasi-, neo-, pre-, proto- Hitlers, Francos and Mussolinis open the door to full-blown fascism. They welcome the violent thugs of Fascism. With their totalitarian intent, with their racism, their hatred and persecution of ethnic, religious and sexual minorities. And with their oppression and suppression of the organs and organisations of the working class such as trade unions, such as Freirean education in Brazil, such as those who proclaim they are communist- illegalised or intimidated or disrupted to varying degrees in Ukraine and in Poland. To take just one 
detailed example, the Polish Parliament has, in mid-2019, passed a law (which could be challenged in the Constitutional Court) to make communism illegal, whereby presenting, sending or owning, for example, Marx's works, a Che Guevara flag or Rosa Luxemburg's books will be punished the same as for the dissemination of Mein Kampf. Capitalists know who their stooges are, who their scapegoats are- and they know their enemies. The greatest threat to their pro-capitalist authoritarian and ultimately fascist rule of terror is the organisedand class-conscious- working class.

Just as rotting fish have an uneven stage of decomposition- heart and brain and innards decay at different rates temperatures vary, so neoliberal authoritarian conservative capitalism decomposes into fascism at different rates and in different circumstances. But decay, they do. Either we throw these rotten fish and their stench out, or the stench will overpower us.

\section{Left Reformis}

The response, to neoliberalism, neoconservatism, neofascism, by left reformists (labour parties, social democratic parties for example), as well as by 'Broad Parties of the Left' (for example, Syriza, Podemos, Die Linke) has been lamentable,. Accepting for three decades the 'inevitability' and even in some cases the 'necessity', the desirability, of neoliberal austerity. Social democratic reformist parties and governments adopted neoliberal austerity policies and thereby became delegitimised, together with the too-often 'accomodationist' trade union and party leaderships. Since the 1970s, political parties and governments that were traditionally 'labour' or 'social democratic' or left of centre, governments- governments that in the 1940s, 1950s and 60s had seen it as their duty to redistribute some wealth and power from the top to the bottom of society- have also subscribed to neoliberal restructuring of economies.

Avowedly Socialist Governments, such as those of Cuba, Bolivia and Venezuela, which have, by and large (though not totally) refused to travel the neoliberal road, have not seen such increasing inequalities. In contrast to neoliberal governments they see their role as to make societies more equal, with both having established free health care and free education, as public rights rather than as commodities to be bought and sold.

In contrast to neoliberal and neoconservative ideology (described below) liberal democratic and social democratic analysis is that capitalism works fine, or can work fine, it just needs some reforms, some improvements. Social democrat parties, whether in their social democratic or their neoliberal incarnations, such as the Labour Party in Britain, 
Australia, and social democratic parties in Scandinavia and Germany, and 'socialist' parties in France, Spain, Portugal, do not want to replace capitalism- they just want to manage it better, to reform it.

They cite, quite correctly, the much more equal economies and societies of northwest Europe, such as Sweden and Finland, for example (and, between 1945 and the mid1970s, of Western Europe in general). and argue that societies become more equal, and happy, with regulation capitalism- with more regulation- over, for example health and medicine standards, food standards, health and safety standards, environmental and ecological protection. The books, The Spirit Level, 2009, and The Inner Level, 2019, by Wilkinson and Pickett, offer powerful evidence to support this, with the most equal societies such as the Scandinavian countries, and Taiwan and Japan, with their concern for communities rather than focusing spectacularly on individuals and individualism, have far less homicide, rape, psychosis, violence and social ills than the most unequal large, rich societies such as the USA and the UK).

Where Marxists disagree with other critics of these widened social and economic inequalities is the Marxist analysis that capitalism has periodic crises, of over-accumulation for example, a crisis of profitability for Capital, a declining rate of profit, and that in times of crisis (such as the recession/ slump of the 1930s, the 'oil crisis' of the 1970s, and the 'Bankers Crisis' since 2008) the capitalist class will always try to tear back from the hands of the workers, the benefits and living standards they and their class organisations (such as trade unions and political parties) had won in more profitable times. The reforms are reversed. Repeatedly, whenever here is a crisis of capitalism, as true today, post 2008 as it was in the 1930s.

That is to say, that in times of economic crisis, of recession, even 'labour' and social democratic governments 'dance to the tune' of national and transnational capitalists- and start cutting the real value of wages/ salaries and social benefits. That it is the poor who pay for the crisis'. This is as true of 'Broad Parties of the Left' as of traditional social democratic, now social democratic neoliberalised (and in some cases, neoconservatised in their anti-immigrant pitches) such as the PS in France, the (pre-2015, pre-Corbyn) Labour Party in the UK, the SDP in Germany, the PS in France, PSOE in Spain, PASOK in Greece.

The extent to which left social democratic parties, as represented, for example, by the Jeremy Corbyn led Labour Party in the UK, can actually take power and move beyond capitalism, as opposed to managing capitalism, is hugely debatable, as it would be, like Tsipras and Syriza in Greece, like Mitterand and his 1980s Union de la Gauche with the 
Communist Party, like the revolutionary government of 1974-1976 in Portugal. Such attempts (as Corbyn's, if elected, and if he can take his parliamentary party with him) are inevitably faced with the full might of national and international forces of capital and its organisations. And the probability of armed coup attempts. And the possibility of international capitalist cavalry charging in- the US military machine. Trump's Secretary of State, Mike Pompeo, has already threatened to do what it takes to stop the socialist Corbyn from taking power- It could be that Mr Corbyn manages to ... get elected. It's possible. You should know, we won't wait for him to do those things to begin to push back. We will do our level best' (Morning Star, 2019).

The mass action needed to support a socialist government, or even a left social democrat government such as that that could be led by Corbyn, needs meticulous and long term organizing on a non-sectarian basis, but with a committed and experienced revolutionary Marxist core- organization, programme, leadership. General Strikes, mass occupations, seizure media would be called for in the face of national and internationally guided coup attempts. But these mass activists cannot be conjured from thin air. Hence the role, in developing class consciousness and an understanding of capitalism and its violence, of Marxist activists- political, trade union, educational.

\section{What is the activist role of Marxist teachers and cultural workers?}

In my writing (e.g. Hill, 2006, 2017a, 2017b) I call for the resistant and the revolutionary role of teachers, academics and education/ cultural workers in different arenas, from national and local electoral and direct action politics/ Focusing on Critical Education, Critical Educators, Marxist Education, Marxist Educators. Resisting, that is, Neoliberal and Neoconservative capitalism, resisting Fascism in its various incarnations.

There are various arenas in which Marxist and Critical Educators and Teacher Educators can be, are, and should be active. Within the:

1) classroom/ seminar room/lecture theatre;

2) wider school community / organization- such as the staffroom, the trade union branch;

3) local community/ town/ city- for example in tenants', benefits', anti-racist, anti-austerity, environmentalist or other local community organizations and movements- and within townwide/ city-wide political parties, social movements and trade unions;

4) national levels in such social movements, parties and organizations. 
I point to these arenas for transformative political social and educational activism since education- whether transformative or reproductive, whether revolutionary, reformist or conservative or reactionary- takes place outside formal schooling and education systems as well as within. Many Marxists engage in what Jennifer Sandlin, Henry Giroux and Mike Cole call 'public pedagogy', and what Marx, Engels, Lenin, Gramsci, McLaren et al call fordeveloping class, political consciousness.

\section{Critical Education, Critical Educators, Marxist Education, Marxist Educators}

Critique, dissent, and transformation are not easy. Critical and Marxist educators engage in critique of educational experiences within the conditions of Capitalism and its current neoliberal and neoconservative form of capitalism. The political context in different states shows the different faces of and interrelationships between calls to religion, armed racist/ neo-Nazi thugs and murders, and chemically treated water-canon used by the police. And, as ideological state apparatuses (Althusser, 1971, Hill, 1989, 2004a) schools and universities themselves have a repressive function with repressive surveillance, punishment and new public managerialist mechanisms and measures to dissuade, and punish, 'deep dissent', 'deep critique'. (Hill, 2003, Rikowski, 2008)

For Marxist and critical educators in general in many states those trying to engage in "deep critique" of capitalism, of capitalist economic, social, and political relations, and how these operate within schools and universities, there is often marginalization, non-promotion, dismissal, pressure to conform to and comply with pro-capitalist norms in ideology. There is pressure of 'performativity', of endless form-filling and surveillance and control of teachers.

\section{MARXISM AND EDUCATION}

In this section of the article I will now focus on some aspects of education and schooling within formal education systems and relate these to various issues in Marxist theory.

Either quietly or openly, in schools, colleges and universities, many radical and Marxist critical educators, as well as others try to affect four aspects of learning and teaching, asking questions and making proposals about (at least) four aspects of educationpedagogy, the curriculum, resistance in the classroom and the hidden curriculum, and the structure of schooling nationally and locally (within-school).. These questions are common to many types of radical and critical educators, not simply Marxists. Below, I add what is 
specifically Marxist about these four issues.

\section{Pedagogy}

Some Critical and Marxist educators question the pattern of teaching and learning relationships and interaction, or teacher-centred pedagogy; what Freire termed 'the banking model' of education. Instead, using, for example, Freirean perspectives and praxis, they try instead, to use democratic participative pedagogy and dialogic education which attempt to break down, to some extent, patterns of domination and submission within classrooms/ seminars and to 'model' non-dominative/submissive' attitudes and relationships for the wider society. Freirean pedagogy is a collaborative enterprise that listens to children's, students' and local communities' voices (Darder et al, 2015, Mayo, 2013, Vittoria, 2016, 2019) and is aimed at collective, social, community empowerment and liberation where education is recognized as intensely political.

Critical Pedagogy did not start with Freire and his Latin American and North American developers and interpreters, although they have codified it. As well as establishing critical pedagogy as a validated university field of education study, they have promoted, in varying degrees, critique of capitalism, imperialism and capitalist-imperialist education, and, particularly in the form of 'Revolutionary Critical Pedagogy' (e.g. McLaren, 2005, 2010). Communist, Marxist and critical educators promote and work with resistance movements at the level of schools/ universities/ social movements, and have been doing so- hundreds of thousands of teachers, ideologues and pedagogues- for the best part of 200 years, throughout the world. This is not to deny the profound impact of Freire on critical education.

Critical and Marxist educators are not the same. Some critical educators are Marxist, some not. Those of us working within a Marxist theoretical, political and practical frame, attempt to utilize different types of pedagogy in teaching, and to engage in non-hierarchical, democratic, participative, teaching and research. Such approaches are rooted in social constructivist Vygotskyan understandings of learning, and are also aimed both at producing co-learning, by teachers as well as taught, and at overtly welcoming and valuing more cultures than are commonly valued in a transmission mode of teaching, that is to say, welcoming and valuing what Gramsci termed `subaltern' cultures. Vygotsky, as a Marxist, was inspired by Marx's dialectic in that his model of teaching and learning rejects top-down and bottom-up accounts of the learning process - these unidirectional models originate in class-based societal relations which Marxists reject. 
In the English-speaking world 'teacher instruction', or 'teacher as instructor' is understood as 'teacher directed', 'teacher centred'. But for Vygotsky instruction is about 'the more knowledgeable other', such as another child or teacher. Teacher's interaction may often include explanations, or 'instructions', but the key feature is the social and shared processes constructing meaning where the teacher, and the others, nudge the child to explain a meaning for him/herself (Vygotsky, 1934).

Of course, critiques of over-dominant teacher-centred pedagogy are not restricted to Marxist educators. They are also made by liberal-progressive, child/ student-centred educators, anarchist educators, and by some conservative educators, concerned about teaching effectiveness and preparation for the workplace in terms of group work skills and also in terms of developing self-directed and self-policed labour. Often following Gramsci, or at least, principles and practices enunciated by Gramsci, Marxist teachers, by virtue of their role in actually teaching, in actually carrying out the role of teacher, need to maintain an authoritative stance. We have a duty to teach, to develop conceptual and critical understanding, to lecture, to facilitate the working-class development of working class organic intellectuals. In this enterprise, learning can be hard work.

In addition to developing an understanding of elite culture and developing 'traditional' intellectual skills, Marxist educators are determined to develop critical consciousness and, as well as valuing rather than demeaning working class life and culture, there is a further characteristic of the work of Marxist educators. It is, echoing Freireans and working class and trade union educators globally, the creation of socialist consciousness, for those in our classrooms and lecture halls, which is grounded in everyday life.

\section{'Grounding' and Activism}

The mode of being of the new intellectual can no longer consist in eloquence ... but in active participation in practical life, as constructor, organiser, "permanent persuader" and not just a simple orator' (Gramsci 1971:10). Gramsci believed that intellectuals need to develop not only intellectual capital to engage with and on behalf of the masses but the social capital of trust and collective will necessary to bring about community-based liberatory praxis'.

Similarly, with regard to the relationship between commitment/ committed action and conscientsization. By struggling we become conscious/aware'. There is a dialectical relationship between conscientization and committed action/struggle. 
Pavlidis (2015) puts it very clearly:

Educators cannot fight for a genuine transformation of society unless they are emotionally, ideologically and politically attached to the social force that mostly needs this transformation. And such a force within capitalism is only the class of wage-labourers. Consequently, educators who strive for social transformation should be perfectly aware of the essential contradiction of capitalist society that necessitates and enables its revolutionary overcoming, and consciously work inside and outside schools, in the fields of social theory and practice, as wage-labour organic intellectuals, contributing to the understanding and expression of its strategic interests, thus serving the cause of the emancipation of labour and humanity.

The role of organic socialist intellectuals is crucial. I am talking of those who intellectualise social, political, cultural, economic matters from the standpoint of what Gramsci termed 'good sense', from a class conscious perspective, such as the 'political' shop steward, or union organizer, the member of a socialist party, the teacher, the youth worker. Herein lies our pedagogical importance, of party, of our organization, of leaflets and newspapers and booklets and books and social media; here, as well as in conversation and in rhetorical speeches, we carry out the role of socialist analysis, of revolutionary pedagogy, of connecting the here and now of a rent strike, a pro-immigrant rally, an anti-austerity march, a picket line of a zero-hours contract employer, an occupation of a tax avoiding multinational company owned shop: here is essential Marxist pedagogy.

Thus critical education is about far more than school or university-based pedagogy. It takes place outside schools and universities as well as inside as the rise of alternatives to the English university (Hill, 2013) and elsewhere. There is educational resistance not only within, but also outside the state-controlled education structures. Marxist teachers, cultural workers, intellectuals, are active within teach-ins at the 'Occupy' occupations, their Tent Cities, the Free University movement, and through oppositional media as well as within trade union and student groups- and within political parties.

\section{Organisation of Students}

A second question that critical and Marxist educators can and should ask concerns the organization of the students. How should children and students of different social class, gender, and ethnic backgrounds and different sexual orientations be organized within classrooms, within institutions such as schools and universities, and within national education systems? Are some groups, such as girls, some ethnic minorities, the working 
class, or the poorer sections of the working class, in fact systematically labelled, segregated, divided, demeaned?

Marxist educators call for a fully Comprehensive Secondary School system so that each school has a broad social class mix and mix of ability and attainment levels. This demands an end to privately purchased schooling and college education and to selective systems of schooling. Existing private schools should be integrated into the state education system - so that the benefits of the private school system are shared amongst all pupils/ students. All schools should be placed under democratic locally elected local council control. Private schools should be prohibited. Religious groups (of any religion) should not be allowed to control and run schools

'Faith Schools' and organised religion should be removed from schooling. If 'people of Faith' wish to teach religion, they should do it in their own time, place of worship (e.g. Friday/ Saturday/ Sunday schools) or in their supplementary or complementary schools. A critical approach should be taken towards religion, recognizing not only its social and personal functions but also its political functions.

In considering how children/ students should be grouped both between schools and within them, there is also a question of how the education system inculcates a differentiated sense of class awareness in working, middle and ruling class students. It tries to keep the working class as a working class that is obedient, subservient, and individualistic, rather than communally oriented. Marxist and other egalitarian educators clearly prefer and work for what in Britain is called 'comprehensive' schools, and in India, for example, is called 'the common school'. But then, even where this happens (as in Finland, where there are only a handful of private schools, where students up to the age of sixteen are taught in common/ comprehensive schools in 'mixed ability' classes) there are internal informal mechanisms operating, such as the hidden curriculum of differentially (classed, 'raced', gendered and 'sexually oriented') expectations and responses to different cultural capitals.

\section{Ownership, Control and Management of Schools and Colleges and Universities}

A third question Marxist and other critical educators ask is about ownership and control of schools (and, indeed, vocational colleges and universities). Who should own, control and govern schools, further education (vocational) colleges and universities? Instead of what is happening under neoliberal rule now, in the USA with Charter Schools, in England with 'Academies'/ Academy schools (state funded schools, i.e. in theory, 'public/ for the public and with public accountability) but, in effect, state funded schools that are privately 
run, managed, controlled. In England, in 2019, well more than half of all secondary schools/ High schools, have been taken out of democratically accountable local authority/ municipal control and handed over to religious organizations, or schools that are run and governed by rich businessmen or women, or by transnational corporations or by national 'for-profit' private companies, by companies that are in theory and public discourse 'not-for-profit' (but which reward handsomely their executives and their friends). To take one example, the head of one chain of Academy schools (the Harris chain of Academies) currently has a salary in excess of $£ 400,000$. This salary comes from public funding for schools in the chain, at the expense of school books and school workers' conditions and salaries. (Hill, 2013; Sodha, 2019)

Marxist educators (and others, of course) believe that schools, colleges and universities should be run democratically, with education workers and students, as well as elected representatives of local communities, having powers in and over those education institutions, within a secular, democratic national framework. Explicit in this is the assertion that education is a public good and a public right that should not be distorted and corrupted by private ownership- there should be no private schools, colleges or universities. (For attempts to address these various aspects of education, in developing a socialist policy for education, see Edwards, Hill and Boxley 2018).

A question related to 'who should own and control schools' is how should they be managed, what should be the style of management - to put it crudely, should it be democratic and participative and collegiate, or should it be authoritarian, dictatorial, top-down control? Associated with ownership and control, are the moves globally towards a more 'dictatorial' style of control and management of the workforce, of teachers, lecturers, school support and administrative staff- New Public Managerialism (NPM). here there is the importation of the huge differentials of pay, perks and power typical of the private sector, into education (and other public services such as health and welfare/ social services).

\section{Curriculum}

A fourth area Marxist and other critical educators can and should critique is the curriculum- who selected the content and how rigid is it? Even where the curriculum is very tightly controlled, even where it is very rigidly prescribed, as in the National Curriculum for Schools in England, or the 'Teacher Training Standards' in England, there are, as Gramsci, taught us, always spaces, little spaces in which to infiltrate, to use, to colonise, that there are always counter-hegemonic struggles, 
Spaces for any significant critique, are circumscribed. Education, and teacher training' in many countries such as the USA and England and Wales have been detheorised. The increasing subordination and commodification of education, including university education, have been well-documented. In England and Wales the government has, in effect, expelled most potentially critical aspects of education, such as sociological and political examination of schooling and education, and questions of social class, 'race' and gender, from the national curriculum for what was formerly called 'teacher education' but is now termed 'teacher training' (Hill, 1989, 2004a).

'How to' has increasingly replaced 'why to' in a technicist curriculum based on 'delivery' of a quietist and overwhelmingly conservative set of 'standards' for student teachers. Teachers are now, by and large, trained in skills rather than educated to examine the 'whys' and the 'why nots' and the contexts of curriculum, pedagogy, educational purposes and structures and the effects these have on reproducing Capitalist economy, society and politics. However, to repeat, there are always spaces for 'resistance' and many teachers and teacher educators try, sometimes very courageously, to resist, to develop critical awareness and understanding.

What follows- socialist curriculum suggestions relating to curriculum content - needs to be taken in the context of the preceding section on Pedagogy, for example, that curriculum content should develop an understanding of elite culture and developing 'traditional' intellectual skills, and that Marxist educators should develop critical consciousness, indeed, critical class consciousness.

Schools, further education/ vocational colleges and universities and adult education and radical informal education should:

(i) Encourage Critical Thinking across the curriculum. Teach children not 'what to think', but also 'how to think'. This includes how to question the curriculum and of any classroom, school, local, national or international community/ society- 'who benefits from this? who loses'?' Children must also be taught to ask 'which (raced and gendered) social class groups and communities win and lose through particular policy and processes', and be taught about Marxist analysis and the class exploitative nature of capitalism as well as current liberal and conservative ideological perspectives on society, but taught from a moralethical perspective/analysis that privileges social justice and Marxist analysis of class society (Pavlidis, 2015). Such critical thinking should include how to think critically not only 
about the media, politicians, the economic and social relations of production, but also about Marxist analysis. Critical analysis should be self-critical.

(ii) Address and value ecological literacy and a readiness to act for environmental justice as well as economic and social justice. Encourage children to 'work for a fairer society with much more equal chances, pay packets and power, and to work against environmental toxicity and despoliation, and for environmental sustainability.

(iii) Ensure that schools' curriculum and the 'hidden curriculum' are anti-racist, antisexist, anti-homophobic- and, in a very, very stark contrast to many books, articles and courses on social justice and equality issues- that the curriculum and the hidden curriculum should actually address, identify, critique, and combat social class exploitation under capitalism, and its attendant class discrimination. Schools and teachers should make sure they encourage equality, welcome different home and group cultures and welcome - rather than labelling, demeaning and degrading-individuals and groups such as the poor. As part of this, anti-bullying practices in every school should be fully implemented. On the issue of social class, too many books and articles and papers addressing inequalities in Education and Society' omit, fail to recognize and address, the issue of social class.

(iv) An honest sex education curriculum in schools that teaches children not just 'when to say no', but also when to say 'yes'. This should be a programme that is focused on positives and pleasure and personal worth, not on stigmatising sex and sexualities.

In more detail:

\section{A Marxist Manifesto for Education}

Elsewhere (Hill, 2010) is set out a Manifesto for Education, partly drawing on an attempt at a Marxist teacher education course (Hill, 2004b). Many - most- of these proposals are supported by other reform and social justice groups. But taken together, they offer a sustained challenge to neoliberal/ neo-conservative, pre-/proto/quasi fascist capitalism.

[1] Small class sizes

[2] Abolish league tables and abolish most externally set assessment tasks

[3] Restore local democratic control of state schools that have been handed over to private corporations, charities and individuals to run, and establish local democratic control of such schools

[4] Establish a fully Comprehensive Secondary School system so that each school has a broad social class mix and mix of attainment levels 
[5] Remove Private Profiteering from Schools/ Education services that have been privatized. Return these services to public/ social control

[6] Integrate private schools and colleges/ universities into the state education system

[7] Remove organised religion from schools and end state Faith Schools.

[8] Provide a good, and local, school for every child

[9] Provide free, nutritious, balanced school meals

[10] Provide free adult education classes, non-vocational and cultural as well as vocational

[11] Restore or establish free, state-funded residential centres and Youth Centres/ Youth clubs

[12] Free up curricula that are over-prescriptive, to move beyond 'the basics curriculum'

[13] Revise school inspectorial and surveillance systems so they are supportive and advisory rather than punitive

[14] Encourage Critical Thinking across the curriculum. Teach children not 'what to think', but 'how to think'. Teach about Marxist analysis and the class exploitative nature of capitalism

[15] Teach in schools for ecological literacy and a readiness to act for environmental justice as well as for economic and social justice.

[16] Ensure that schools are anti-racist, anti-sexist and anti-homophobic and are environmentalist

[17] Provide an honest sex education curriculum in schools that teaches children not just 'when to say no', but also 'when to say yes'.

[18] Develop proper recognition of all school workers, with no compulsory job redundancies

[19] Set up school councils which include student as well as teacher and nonteacher worker voices

[20] Broaden teacher education and training on the detailed lines suggested below, so it is theorised and socially and politically contextualised, not restricted (primarily or totally) to technical 'delivery' and control skills

[21] Set up a completely Free, fully funded, publicly owned and democratic education system from pre-school right through to university, with no fees, and with financial grants for poorer students post 16 and for further and higher education. 
To repeat, most of these proposals would be accepted by social democrats. But, I want to stress here- Marxists develop and propagate them in the context of the three basic principles of Marxism set out earlier. Social democrats don't.

\section{Teacher Education: an Eco-Marxist Policy}

Now, congruent with these proposal for teacher education/ training (based on Edwards, Hill and Boxley 2018) are proposals for a Marxist manifesto for teacher education for economic, environmental and social justice. Such a programme should:

- Engage in pedagogic theory in which the socio-political, economic and environmental contexts of schooling and education are explicit. This includes understanding of children, schooling, society and nature, their inter-relationships, and alternative views and methods of, for example, classroom organization, schooling, and the economic and political relationship of schooling to society and nature;

- Develop equal opportunities policies and praxis so that children do not suffer from labelling, under-expectation, stereotyping or prejudice;

- Enable student teachers to develop as critical, reflective teachers, able, for example, to decode media, ministerial (and indeed, Radical Left) distortion, bias, and propaganda. This encourages the development of teachers, able to interrelate and critique theory and practice (their own and that of others);

- Include not only technical reflection, but also Marxist critical reflection, so as to question a particular policy or theory, and to ask such critical questions as 'whose interests are served?'; 'who wins?' (if only by legitimating the status quo) and 'who loses?';

- Enable student teachers to understand the social, economic and environmental inequalities and injustices present in their places of work and communities, and to challenge them.

\section{Curriculum Content}

The first three areas of Curriculum Content below are common across different ideological positions. Because of their near universality these are not developed here. The next two are also widely shared. The final ten propositions, 6 to 16, are more specifically eco-Marxist/ Radical Left.

The Initial teacher Education (ITE) Curriculum should include: 
(1) Classroom skills and competencies. Teachers need reflective skills and understanding of learning, teaching and classroom management.

(2) Subject Knowledge.

(3) The development of higher level analytical and intellectual skills. This demands that teachers are capable of acting and thinking at an abstract level as understood by, for example, Vygotsky's 'scientific' thinking.

(4) Support for a major role for higher education institutions in ITE and opposition to school-led routes. Higher Education institutions focus on developing the theoretical perspectives outlined above, promoting the advance of pedagogy through a theorypractice dialectic.

(5) Welcoming of different routes into teaching concordant with graduate teacher status and the above principles.

(6) A commitment to economic, social and environmental justice, and recognition of the interconnection between the three. If equal opportunities policies stop at celebrating cultural diversity and establishing positive and non-stereotypical role models, and do not see themselves as a development of broader economic justice, then they can be viewed as, in essence, conservative, for failing to challenge the status quo, based as it is on (raced and gendered) social class exploitation.

(7) Research evidence on equality issues: on racism, sexism, social class inequality, homophobia, and discrimination/ prejudice/ regarding disability and special needs, and the intersection of these factors with economic and environmental inequalities.

(8) A class-based approach to social, economic and environmental justice in the curriculum.

(9) Skills in dealing with the incidence of classist, homophobic, racist, and sexist remarks and other types of harassment at various levels, such as within the classroom and throughout the institution and society.

(10) Developing within institutions open fora on social and ecological justice where students and staff in institutions can meet in a supportive environment.

(11) Critiques of competing approaches, ideologies, curricula, pedagogies of schooling, teacher education and society.

(12) Developing knowledge and skills to critically examine the ideological nature of teaching and the nature of teachers' work.

(13) The concurrent rather than the consecutive development of critical reflection, throughout and from the beginning of the ITE course. If the social context of 
schooling is left until 'post-initial training', many Newly Qualified Teachers will not have post-initial training other what are, currently, instrumentalist in-service training concerned with how to 'deliver' results.

(14) Substantially predetermined rather than primarily negotiated curriculum objectives/ Should a critically reflective teaching program have predefined content or be negotiated? At various times the focus has been on programme content, critical analysis and curriculum development, pedagogic relationships between teachers/ teacher educators and pupils/ students. Arguably, heavy use of learner-centred discussion militates against the development of the broad span of critical theoretical insights argued for here. For organic intellectuals, the goal is not to tell the people what to think' but to enable them to think clearly to provide them with the tools such as critical literacy to engage in cultural action incorporating the exercise of critical (dialectical) consciousness aimed at social transformation.

(15) The application of critical evaluation to school-based practice and experience. Theory can provide the analytic and conceptual apparatus for thinking about practice, within the formal and hidden curriculum, while practice can provide the opportunity for the testing and assimilation of theory. Successive governments in the USA and UK for example have prioritised school-led and school-based ITE programmes. The detheorization of teacher education is a major problem in the development of effective teaching, critical skills, awareness and teaching, and in the development of a revolutionary transformative critical pedagogy.

(16) Environmental justice pedagogy. This entails active engagement between students, communities and the environment and addresses complex social, economic and environmental issues so that students can develop critical, historical and transformative knowledge. This is important for students and teachers living and working in economically disadvantaged urban communities - because it can reorient the curriculum to deal with specific environmental justice issues that these communities face.

\section{Resistance in the classroom}

Of course, many educators, students and communities, do offer resistance from a variety of ideological perspectives. This is so especially in the inner-cities, where questions of social class, inequality, poverty, race are part of the material and cultural reality of everyday life. 
Marxist educators, indeed critical educators in general, can, with students, look at the curriculum and ask, 'Who do you think wrote this? 'We can question existing versions of history. We can ask, 'is there a different version or view of the past, the present, or the future?'. The question, 'who wins, who loses?' when related to social class is a key question that can be interrogated of any micro-, meso, or macro- policy- such as the content of a curriculum, pedagogy, the hidden curriculum, or of wider historical, cultural, economic, political developments and policies and 'common sense'. Which ('raced' and gendered' social class, or social class fractions, 'win' or 'lose out'- and how. And why!

Where Marxist educators, and Revolutionary Critical Educators (McLaren, 2005, 2010) (in effect, Marxist educators, but using a different nomenclature- it's difficult to call yourself a Marxist in the USA) differ from more social democratic and liberal critical educators. Marxists differ from 'Marxian' writers such as Michael W Apple- brilliant, like Giroux, on critique, and on 'reforms', but Apple is not a revolutionary Marxist, but a revisionist or reformist Marxist). Marxists (classical Marxists, revolutionary Marxists) place more emphasis on socialist transformation, on ending, surpassing, capitalism. Social democratic and liberal/ liberal-progressive educators do not proclaim the need for an anticapitalist revolution, the need to replace capitalist economic and social relations by socialist ones. That's a key difference.

\section{What is specifically about these four education proposals?}

Marxists work for and willingly embrace reforms, they are committed to three forms of analysis and action, that social democrats, radical liberals, radical democrats, non-Marxist feminists, non-Marxist anti-racists, and non-Marxist Queer activists are not.

These three forms of analysis are:

\section{Class Analysis: the Capital- Labour Relation}

2. Capitalism must be replaced by Socialism and that change is Revolutionary

3. Revolutionary Transformation of Economy and Society need to be preceded by and accompanied by a Class Programme, Organisation, and Activism

\section{Class Analysis: the Capital- Labour Relation}

The first distinguishing feature for Marxists is the salience of class as compared with other forms of structural oppression, discrimination and inequality. Marxists in general Marxist Feminists, Marxist anti-Racists, Marxist Queer Theorists stand together with social movements and civil rights campaigners in opposing racism, sexism, homophobia, and other 
forms of discrimination. And support reforms suggested, enacted by non-Marxist reformists, together with social movements and civil rights campaigners But Marxists go further than criticizing (and acting against) social discrimination, oppressions, into economic rights. And further than that, into the recognition that full economic rights cannot be achieved under a capitalist economic system, but only under a socialist or communist (socialism being the stage on the road to full communism). Furthermore, it is recognized that it is only the organized working class (black-white; male-female; straight-LGBT, Dalit and all other castes) that can organize and succeed in replacing the Capitalist system

The Communist Manifesto (Marx and Engels, 1848/1977) is startlingly powerful and relevant today in its analysis of capitalism. Capitalism, as analysed and criticized by Marxists, is the systematic exploitation by the capitalist class of the labour power of the working class(es), with the capitalists appropriating the surplus value created by the laboutr of the working class(es). This is the relationship between Capital and Labour- the CapitalLabour Relation. With capitalists pocketing this surplus value as profit.

There is, under capitalism, a continuous 'class war', a continuous antagonistic relationship between the exploiting class and the exploited class, whatever the state of subjective appreciation/ understanding/ political and class consciousness is. Each of the two (major) classes of society engaged in struggle over increasing the proportion of surplus value (the value left when raw materials, rents, and wages/salaries have been paid) that should go into capitalists' pockets as profits, or into workers' pockets as wages, and, as welfare benefits- the social wage. In the words of The Communist Manifesto, 'society as a whole is more and more splitting up into two great hostile camps, into two great classes directly facing each other: Bourgeoisie and Proletariat" (Marx and Engels, 1848/1977). In today's language, the $0.1 \%$, 'the rulers of the universe', and most of the rest (Picketty, 2014; Hill, 2017c).

More broadly, the struggle is over ownership of the means of production (Ebert and Zavarzadeh, 2002). The struggle over the distribution of surplus value is a trade-unionist struggle (as Lenin points out in What Is To Be Done) that does not go beyond the limits of "what is": capitalist relations. There is a "social wage" only in the parameters of capitalism, which in fact makes those social wages necessary (because of exploitation for surplus value that leaves workers unable to meet their needs).

And it is the state apparatuses that not only keep the working class, this workforce, trained and fit to work-schools, universities, and health services — but that also attempt to 
keep the working class in a state of 'ideological acquiescence', to believe that with regard to how society, the economy and politics are ordered, 'there is no alternative'.

\section{Capitalism must be replaced by socialism and that change is revolutionary}

Marxists believe that reforms are not sustainable under capitalism, even if, when they are implemented, they are hugely or minimally welcome to Marxists. However, they are unsustainable, and are stripped away when there are the (recurrent and systemic) crises of capital, as happened in the 1930s, 1970s, post 2008).

I want to emphasise here that social democratic parties and politicians, such as Pablo Iglesias and Podemos in Spain, Alexis Tsipras and Syriza in Greece, Jeremy Corbyn and the majority of the Labour Party membership in the UK, Bernie Sanders and Alexandria Ocasio-Cortes in the USA, do not want and have never wanted to replace capitalism- they just want to manage it better, to regulate it, to reform it- to make it work better, with more 'social justice', and with what Lenin called 'trade union demands', for increasing the social wage and the individual wage and collective wage of workers, with 'better management of capitalism' understood to mean the more equitable distribution of surplus value.

In classical Marxist analysis capitalism is never acceptable, whether regulated, reformed, social democratic or not, because it is the exploitation (economic, therefore political, cultural, social oppression) of humans by humans. Hence what defines classical Marxists is a belief, an analysis, that capitalism must be replaced per se/ in itself, regardless of the degree or sustainability / non-sustainability of reforms under capitalism.

This is an important point: it is why Marxists, activist Marxist teachers, work to develop class-consciousness, a sense of the working class being 'a class for itself' (its class position) as opposed to 'a class in itself ' (a class with class consciousness) (Marx, 1847) a class with 'good sense' as opposed to 'common sense' (Gramsci, 1971), for in capitalist society, under conditions of class exploitation, as Pavlidis (2015) puts it 'workers spontaneously can develop only a trade-union consciousness, which does not exceed the horizon of their individual claims within the framework of the bourgeois society, and signifies 'the ideological enslavement of the workers by the bourgeoisie" (Lenin, 1902/2008).

The link between workers' consciousness and socialist revolution is to teach against, to subvert, this 'ideological enslavement', in order that workers of the world can unite, as 'a class for itself' and break the chains that bind them. Class-consciousness does not follow automatically or inevitably from the fact of class position. The Communist Manifesto (Marx and Engels, 1848) explicitly identifies the "formation of the proletariat into 
a class" as the key political task facing the communists.

Therefore what is needed is a revolution to replace, to get rid of, the capitalist economic system with its capitalist economic relations of production and its capitalist social relations of production- the ownership by capitalists of the wealth and the power in society.

An elected socialist government would not be able to bring about much change which went against the interests of the capitalist class because the military, judiciary, police and corporate hierarchy are not democratic. The national and global capitalist class use state violence, and/ or the instruments of global or US capitalist economy or military to stop Socialism.

The ballot box alone cannot bring about revolution because state institutions in capitalism are not democratic. A Congress or Parliament or president or Prime Minister has limited power over these institutions, as we can see with the power of 'the Deep State' in Trump's USA. For revolutionary Marxists, a socialist revolution is necessary, so that there comes into power (not just into government) an egalitarian, socialist economic, political and education system.

\section{Revolutionary Transformation of Economy and Society need to be preceded by and accompanied by a Class Programme, Organisation, and Activism}

The third point of difference between Marxist and non-Marxist radicals is that in order to replace capitalism, Marxists have to actually work to organize for that movement, for that action. Thus a duty as a Marxist is activist praxis, within the limits of one's ability and competing demands. Most Marxists move beyond proposal into activism and praxis- praxis is action guided by theory, or theory in motion. As focuses on activity within formal teacher education courses and its wider education structures. As Marx notes, 'philosophers have only interpreted the world. The point is to change it'.

Marxists, recognise that political organization, programme development, and political intervention are necessary. They have to be fought for and developed - and defended. And a particular type of activist praxis is called for, to the extent of one's capabilities, that is, for Marxist educators to act as, to be, to become, 'organic intellectuals'. Revolutions do not fall off trees, like apples. As Lenin, in 'State and Revolution' (1918) wrote, socialist revolutions have to be fought for- and defended.

Conclusion: educate, agitate, organise 
Both in the education arena and in the wider society, we Marxists seek to serve and advance the interests of the working class- recognising the fundamental nature of class exploitation and the multiple oppressions based on identities and subjectivities. We, as teachers, as educators, are working class, too: we sell our labor power to capitalists and to the apparatuses of the capitalist state, such as schools and universities. We have to consistently and courageously challenge the dominant ideology, the hegemony of the ruling class, the bourgeoisie, the capitalist class. We have to contest the currently hegemonic control of ideas by the capitalist state, schools, media, and their allies in the institutions of religion.

But the situation we face is not just a war of ideas, an ideological war: it is also an economic class war, where the social and economic conditions and well-being of the working class are threatened and undermined by the ruling class and its capitalist state goes even further, and argues that contemporary and future capitalist onslaughts will result in deaths for 'superfluous' workers and sections of the non-working industrial reserve army.

The precise organisation and characteristics of the resistance to the depredations, these neoconservative, neoliberal and neofascist outrages, is a matter for strategic and tactical considerations, relating to the current balance (strength, organisations, (dis)-unity) of class forces in specific local and national contexts.

What is clear is that the task regarding capitalism, for Marxist activists and educators, is not just to reform capitalism, welcome though such reforms are, and we must be active in campaigning for and protecting such reforms. But, regarding capitalism, our task is to replace it with democratic Marxism. As teachers, as educators, as cultural workers, as activists, as intellectuals, we have a role to play. We must play it. To repeat an earlier phrase, 'Either we throw these rotten fish and their stench out, or the stench will overpower us'.

\section{REFERENCES}

Althusser, L. (1971) 'Ideology and state apparatus'. In Lenin and Philosophy and Other Essays. London: New Left Books.

Bellamy Foster, J. (2017) NeoFascism in the White House. Monthly Review, 1 April. Online at https://monthlyreview.org/2017/04/01/neofascism-in-the-white-house/

Darder, A., Mayo, P. and Paraskeva, J. (2015) International Critical Pedagogy Reader. London and New York: Routledge.

Ebert, T. and Zavarzadeh, M. (2002) 'ABC of Class'. The Red Critique, 7, (November/December 2002). Online

http://www.redcritique.org/NovDec02/printversions/abcofclassprint.htm 
Edwards, G., Hill, D. and Boxley, S. (2018) Critical Teacher Education for Economic, Environmental and Social Justice. Journal for Critical Education Policy Studies 16(3). Online at http://www.jceps.com/wp-content/uploads/2019/01/16-3-1.pdf

El-Gingihy, Y. (2018) Karl Marx 200th anniversary: The world is finally ready for Marxism as capitalism reaches the tipping point. The Independent, 4 May. Online at https://www.independent.co.uk/news/long reads/karl-marx-anniversary-a8334241.html

Freire, P/ (1972) Pedagogy of the Oppressed. London: Penguin.

Giroux, H. (2004) Terror of Neoliberalism: Authoritarianism and the Eclipse of Democracy. New York: Routledge.

Gramsci, A. (1971) Selections from the Prison Notebooks. Hoare, Q. and Nowell Smith, G. (eds. and trans.) New York: International Publishers.

Harvey, D. (2005) A Brief History of Neoliberalism. Oxford, England; Oxford University Press.

Hill, D. (1989) Charge of the Right Brigade: The Radical Right's attack on Teacher Education, Brighton: Institute for Education Policy Studies.. Online at www.ieps.org.uk/PDFs/hill1989.pdf

Hill, D. (2003) Hill, D. (2003) (second edition) Brief Autobiography of a Bolshie Dismissed. Brighton: Institute for Education Policy Studies. Online at http://www.ieps.org.uk.cwc.net/bolsharticle.pdf

Hill, D. (2004a) Books, Banks and Bullets: Controlling our minds- the global project of Imperialistic and militaristic neo-liberalism and its effect on education policy. Policy Futures in Education, 2, 3-4, pp. 504-522 (Theme: Marxist Futures in Education). Online at http://firgoa.usc.es/drupal/files/hill.pdf

Hill, D. (2004b) Critical Transformative Teacher Education: a four-year Marxist undergraduate programme for student teachers: contexts, intents, constraints and effects. Paper presented at the British Education Research Association Annual Conference, Manchester Metropolitan University, England, Sept, 2004. Online at http://www.ieps.org.uk/papers1.php

Hill, D. (2006) Class, the Crisis of Neoliberal Global Capital, and the role of Education and Knowledge Workers. FirgoaUniversidadePublica. Online at http://firgoa.usc.es/drupal/node/47262

Hill, D. (2010) A Socialist Manifesto for Education. Online at http://www.ieps.org.uk/PDFs/socialistmanifestofored.pdf

Hill, D. (2012) Immiseration capitalism, activism and education: Resistance, revolt and revenge. Journal for Critical Education Policy Studies, 10(2). Online at http://www.jceps.com/index.php?pagelD=article\&articlelD=259.

Hill, D, (ed.). (2013) Immiseration Capitalism and Education: Austerity, Resistance and Revolt. Brighton, England: Institute for Education Policy Studies. 
Hill, D. (2017a) Class, Race and Education Under Neoliberal Capitalism. New Delhi, India: Aakar Books

Hill, D. (2017b) The Role of Marxist Educators Against and Within Neoliberal Capitalism. Insurgent Scripts, January. New Delhi: Insurgent Scripts. Online at http://insurgentscripts.org/the-role-of-marxist-educators-against-and-within-neoliberalcapitalism/

Hill, D. (2017c) La educación marxista contra el capitalismo en la era neoliberal (Marxist Education Against Capitalism in the Neoliberal Era). Nuestra Bandera: Theoretical Journal of the Spanish Communist Party, 236.

Hill, D. (2018) Education and social class: a Marxist response. In R. Simmons and J. Smyth (eds.), Education and Working Class Youth. London: Palgrave MacMillan. Pre-publication copy online at http://www.ieps.org.uk/media/1140/hill-2018-education-and-social-class-in-rsimmons-and-j-smyth-education-and-working-class-youth-pre-publication-proofs.pdf

Lenin, V. I. (1902/2008) What Is To Be Done? Burning Questions of Our Movement. Marxist Internet Archive. Online at https://www.marxists.org/archive/lenin/works/1901/witbd/

Lenin, V. I. (1918/1999) The State and Revolution: The Marxist Theory of the State \& the Tasks of the Proletariat in the Revolution. Online at https://www.marxists.org/archive/lenin/works/1917/staterev/

Marx, K. (1845/2002) Theses on Feuerbach. Online at https://www.marxists.org/archive/marx/works/1845/theses/

Marx, K. (1847/1999) The Poverty of Philosophy. Online at https://www.marxists.org/archive/marx/works/1847/poverty-philosophy/

Marx, K. and Engels, F. (1848/2010) The Communist Manifesto. Marxist Internet Archive. Online at https://www. marxists.org/archive/marx/works/download/pdf/Manifesto.pdf

Mayo, P. (2013) Echoes from Freire for a Critically Engaged Pedagogy. London: Continuum.

McLaren, P. (2005) Capitalists and Conquerors: A Critical Pedagogy Against Empire. New York: Rowman and Littlefield.

McLaren, P. (2010) 'Revolutionary Critical Pedagogy'. Interactions: UCLA Journal of Education and Information Studies, 6 (2) Online at http://escholarship.org/uc/item/7qj2b570

Morning Star (2015) Trump administration's threat to sabotage Corbyn reveals its 'contempt for democracy'. London: Morning Star, 10 June. Online at https://morningstaronline.co.uk/article/b/trump-administrations-threat-to-sabotage-corbynreveals-its-contempt-for-democracy

O'Toole, F. (2019) Trial runs for fascism are in full flow. Irish Times, 26 June. Online at: https://www.irishtimes.com/opinion/fintan-o-toole-trial-runs-for-fascism-are-in-full-flow$\underline{1.3543375}$

Oxfam (2018) Press Release: Even it Up. Online at https://www.oxfam.org/en/pressroom/pressreleases/2018-01-22/richest-1-percent-bagged82-percent-wealth-created-last-year 
Pavlidis, P. (2010) 'Social consciousness, education and transformative activity'. Journal for Critical Education Policy Studies, 13(2). Online at http://www.jceps.com/archives/2611

Picketty, T. (2014) Capital in the Twenty-First Century. Cambridge, MA, USA: Harvard University Press.

Rikowski, G. (2008) The compression of critical space in education today. The Flow of Ideas. Online at http://www.flowideas.co.uk/?page=articles\&sub=Critical\%20Space\%20in\%20Education

Rosen, D. (2018) Is the US in a Pre-Fascist Period?. Counterpunch, 28 Sep. Online at https://www.counterpunch.org/2018/09/28/is-the-u-s-in-a-pre-fascist-period/

Sodha, S. (2018) The Great Academy Schools Scandal. The Guardian, 22 July. Online at https://www.theguardian.com/education/2018/jul/22/academy-schools-scandal-failing-

$\underline{\text { trusts }}$

Thomas, M. L (2019) Fascism in Europe Today. International Socialism, 162, April. Online at http://isj.org.uk/fascism-in-europe-today/

Vittoria, P. (2016) Narrating Paolo Freire: towards a pedagogy of dialogue. Brighton: Institute for Education Policy Studies.

Vittoria, P. (2019) Paulo Freire and Augusto Boal: Revolutionary Praxis in theatre and education. Brighton: Institute for Education Policy Studies.

Vygotsky, L.S. (1934). Thinking and Speech. Online at https://www.marxists.org/archive/vygotsky/works/words/Thinking-and-Speech.pdf

Wilkinson, R. and Pickett, K. (2009) The Spirit Level: Why more equal societies almost always do better. London: Allen Lane

Wilkinson, R. and Pickett, K. (2019) The Inner Level: How More Equal Societies Reduce Stress, Restore Sanity and Improve Everyone's Well-being. London: Penguin. 